\title{
Politik som trykte liv
}

\section{AF HENRIK BØDKER}

Politikere er i den trykte presse konstruerede som forskellige konstellationer af ideologi, biografi, politisk løbebane og resultater samt holdninger til konkrete sager og, ikke mindst, af køn, etnicitet og andre kulturelle aspekter. Hvad det vil sige at være politiker er således et resultat af løbende forhandlinger imellem journalister, politikere og læsere - der hver især har forskellige, kulturelt og historisk betingede, forestillinger om hvilke faktorer, der er de mest relevante for opbygningen af politisk identitet. Det projekt som denne artikel udspringer af har som mål at analysere sådanne processer ved at se nærmere på tilblivelsen og vedligeholdelsen af Naser Khaders politiske identitet i en række landsdækkende dagblade.

„Jeg interviewede også Hillary Clinton nogle få gange“,1 skriver tidligere New York Times journalist Elizabeth Kolbert i en anmeldelse af to af de seneste biografier om Hillary i The New Yorker (hvor Kolbert nu arbejder som skribent). „Når det drejede sig om politik var hun altid skarp og engageret“, påpeger Kolbert om sine interviews med Hillary og fortsætter: „men når det omhandlede mere personlige emner var det som at tale med en igennem flere lag plexiglas. Jeg var selvfølgelig interesseret i at trænge ind til den 'rigtige' Hillary. [men] (Set ud fra et ønske om at få det fulde billede var der uendeligt langt igen) “ (Kolbert, 2007: 134). Selvom Kolbert mener, at det at "mange amerikanere“, selv efter alt, der er blevet sagt og skrevet, „stadig mener, at de ikke kender den rigtige Hillary, på en eller anden måde i sig selv må sige noget om hvem Hillary egentlig er“, så er Kolberts journalistiske instinkt, 
hendes journalistiske interesse i "full disclosure", skyld i en stadig frustration over ikke helt at kunne få fat på den egentlige Hillary. „Det ville være interessant at vide hvad hun egentlig føler“, skriver Kolbert hen imod slutningen af sin anmeldelse og tilføjer „og man kan argumentere for, at sådanne informationer er relevante for vælgerne“ (Kolbert, 2007: 134). Spørgsmålet er imidlertid, hvor sådanne „oprigtige“ oplysninger skal komme fra - fra Hillary selv eller i samarbejde med journalister/biografer eller alene fra sådanne skribenter?

Hvad enten man arbejder med, uden eller imod Hillary, så er det jo åbenlyst, at politikeres liv i en eller anden forstand er politiske. Eller de bliver det i hvert tilfælde i kraft af de processer, hvor igennem disse liv konstrueres for offentligheden. „[D]er findes to slags bøger om [Hillary] Clinton“ skriver Kolbert: „,D]en første slags forsøger at bevise, at hun i virkeligheden er langt værre, end du tror; den anden, at hun faktisk ikke er værre end du tror, hun er“ (Kolbert, 2007: 130). Nyhedsværdien af sådanne bøger eller artikler er således et løfte om at afsløre noget, der enten vil forandre eller bibeholde de offentlige fremstillinger, der i vid udstrækning er formet igennem den daglige nyhedsdækning af de politiske processer, politikerne er eller har været involveret i. Et af de definerende karakteristika, der er blevet hæftet på journalistikkens fremkomst - og stadige virke - er netop „det at konstruere politik i en offentlig form“ (Conboy, 2006: 28). Det eller de offentlige billede(r), hvor igennem en politikers karakter tegnes, er således noget, der konstant udvikler sig samt ydermere noget, der er vanskeligt at bestemme, idet der findes en lang række forskellige billeder, alt afhængig af den særlige mediematrix, der ligger til grund for billeddannelsen.

Det er dog samtidig klart, at den politiske journalistik trækker på en række mere eller mindre fælles medierede livsforløb, der løbende udvides, nuanceres og/eller modsiges. Det giver derfor kun mening at tale om en form for ,afsløring“, hvis det, der afsløres, bryder med eller vedligeholder allerede etablerede forestillinger. Som enhver (selv-)biografi er forestillinger om livsforløb baseret på en række begivenheder, der - af forskellige årsager anses som vigtige, og som fortællingen kæder sammen. De fremstillinger, hvor igennem Hillary er blevet tegnet, er til eksempel 
baseret på hendes liv som førstedame, hendes mands utroskab og retssag, den kuldsejlede velfærdsreform hun stod i spidsen for som førstedame, hendes rolle i den såkaldte "Whitewater" sag, hendes karriere som senator for New York og endelig hendes liv som præsidentkandidat. Disse, og flere, begivenheder er således både et resultat af og udgangspunkt for journalistiske fortællinger, fortællinger, der ydermere drives af, at hovedpersonen er en kvinde - hvilket blandt andet kan ses som en af hovedårsagerne til Kolberts interesse i, hvad „hun egentlig føler“. En (kommende) politikers liv og livsforløb bliver ofte en journalistisk begivenhed i sig selv i de tilfælde, hvor hans eller hendes forløb afviger fra de etablerede forestillinger om, hvad en politiker er eller bør være. Dette gælder i høj grad også Hillarys væsentligste opponent i det demokratiske partis primærvalg Barack Obama, en farvet søn af en hvid amerikansk kvinde og en sort mand fra Kenya. Og det gælder også, som det vil fremgå nedenfor, for Naser Khader.

Min undersøgelse af de relationer, der konstrueres i den politiske journalistik imellem biografi, karakter og politiske begivenheder fokuserer derfor på tilblivelsen af Naser Khaders som offentlig person. Mit overordnede mål i projektet er at følge denne eller disse konstruktion(er) i henholdsvis den trykte presse og biografier, fra han gør sin entre på den landspolitiske scene op til i dag. Konstruktionen af Khader som offentlig person er selvsagt ikke begrænset til disse medier. TV, radio, internet og magasiner spiller vigtige roller; og de konstruerede livsforløb er i den forstand, og i stigende grad, flermedielle. Et vigtigt, men vanskeligt spørgsmål er her, hvorledes den trykte politiske journalistik har udviklet sig i relation til en mediematrix i stadig bevægelse. Med hensyn til den tidslige udvikling er etableringen af Ny Alliance samt valgkampen frem til d. 13. nov., 2007 selvsagt nye og vigtige begivenheder. Disse har imidlertid ikke været udgangspunktet for projektet. Det overordnede mål med projektet er, at det kan være med til at belyse, hvordan forskellige troper og grænseflader for persontegningen af politikere har udviklet og forskubbet sig i den trykte presse de sidste 10-15 år i Danmark. Dette projekt er imidlertid blot i sin begyndelse og nærværende artikel har derfor det mere beskedne mål at udpege nogle begreber samt pro- 
blemfelter for det større projekt. Udgangspunktet for dette indledende arbejde udgøres af materiale fra den trykte presse i forbindelse med etableringen af Ny Alliance. Materiale fra biografier og andre medier vil således ikke i nævneværdigt omfang blive diskuteret i denne artikel.

Khaders politiske løbebane er forholdsvist typisk. Han blev interesseret i politik, mens han gik i gymnasiet og meldte sig i 1984 ind i det Radikale Venstre. Han var da 21 og læste statskundskab på Københavns Universitet. Fra 1997-200o var han medlem af borgerrepræsentationen i København og har siden 2001 været medlem af Folketinget. Det, der gør Khader speciel i en dansk sammenhæng, er sammenkædningen imellem denne „klassiske“ løbebane og så hans etniske baggrund. I 1974, da Khader var ni år, blev han sammen med sine fire søskende og sin syriske mor forenet med sin palæstinensiske far i Danmark. Khader har således været positioneret henholdsvis som en succesrig politiker, der tilfældigvis havde et etnisk ophav, der er forskelligt fra de fleste danskeres, og så det man kan kaldte en etnisk politiker, der repræsenterer noget ,etnisk“ snarere end, eller ud over, en given og accepteret politisk ideologi. Dette skyldes blandt andet, at Khader, af forståelige årsager, har deltaget aktivt i sager, der omhandler immigration, integration og dermed relationerne imellem politik og religion.

For at forstå Khaders politiske og offentlige liv er det derfor nødvendigt at medtænke den øgede fokus, der har været på forskellige aspekter af immigration i det politiske landskab siden midten af 199oerne. Dette hænger ikke mindst sammen med etableringen af Dansk Folkeparti i 1995. Khader har fra starten positioneret sig selv i opposition til både de xenofobiske tilbøjeligheder, der vokser ud af mere essentialistiske opfattelser af dansk kultur, og de mere afbøjende kulturrelativistiske holdninger ifølge hvilke, der bør stilles få eller ingen værdirelaterede krav til immigranter. Den første gang Khader optræder som skribent i et landsdækkende dagblad, Berlingske Tidende i 1995, er med en kommentar til en anden skribents indsigelse imod Khaders udtalelser på TV om undervisningen i danske skoler, der er funderet på islam. I denne kommentar forsvarer Khader sine synspunkter om, at denne undervisning modarbejder integrationen og udvik- 
lingen af de pågældende immigrantbørn. Denne grundholdning til mødet imellem islam og det danske samfund dannede senere grundlag for etableringen af Demokratiske Muslimer i forbindelse med sagen om Muhammed-tegningerne i 2005-6. Udviklingen af Khaders synlighed i de landsdækkende dagblade er repræsenteret numerisk i følgende figur.

\section{Figur 1}

Antal artikler i hvilke navnet Naser Khader indgår.

I hele artiklen

Antal artikler

I overskriften

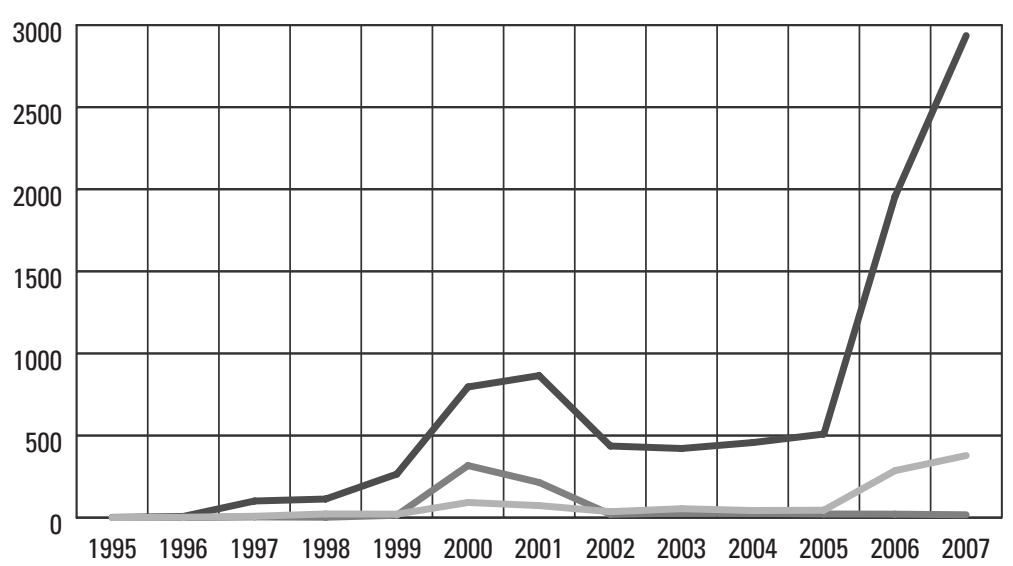

Kilde: www.infomedia.dk. Tallene i anden halvdel af 2007 er estimeret på baggrund af de første seks måneder. På grund af det udskrevne folketingsvalg er dette estimat dog for lavt.

De perioder, hvor der kan iagttages en markant stigning i antallet af artikler i flere af de tre kategorier i ovenstående figur, er henholdsvis perioden omkring 2000-1 og så fra $2005 \mathrm{og}$ frem. Den første af disse hænger primært sammen med Khaders kampagne for at blive valgt til Folketinget (samt hans arbejde i Købehavns borgerrepræsentation - der sluttede i 200o), mens stigningen fra 2005 skyldes Khaders eksponering og „intervention“ i Muhammed-krisen igennem etableringen af „Demokratiske Muslimer“. At kurven ikke er faldet siden da skyldes, at Khader i de lange efterdønninger fra denne begivenhed i maj 2007 meldte sig ud af det Radikale Venstre og etablerede sit eget parti, den Ny Alliance sammen med de to Europa-parlamentsmedlemmer Anders Sa- 
mulelsen (også fra det Radikale Venstre) og Gitte Seeberg (fra det Konservative Folkeparti). Det overordnede mål med dette parti, der blev præsenteret ved en pressekonference den 7. maj, var at etablere en ny liberal midte i dansk politik, der kunne sikre regeringen et parlamentarisk grundlag uden om Dansk Folkeparti. Ny Alliance tiltrak sig hurtigt et stort antal medlemmer og fik indsamlet underskrifter nok til at kunne stille op til folketinget. I skrivende stund står de til at få ti mandater ved det valg, der skal afholdes d. 13. november. Eftersom Ny Alliance ikke have et færdigt partiprogram - hvilket var noget, der skulle udvikles - kan en stor del af den tidlige (og senere?) succes tilskrives Khader og de politiske muligheder og/eller værdier, der kan siges at være forbundet med hans politiske identitet.

At der etableres nye partier ved, at folketingsmedlemmer melder sig ud af det parti, de blev valgt for, er langt fra uset i dansk politik. Når det sker, er det dog stadig en væsentlig politisk begivenhed, og samtlige landsdækkende dagblade havde da også denne begivenhed på forsiden tirsdag d. 8. maj - dagen efter pressemødet. På baggrund af disse forsider, der hver især håndterer partidannelsen på forskellig vis, vil jeg nedenfor fokusere på nogle af de problemfelter og analytiske parametre, der vil ligge til grund for det større projekt omkring konstruktionen af livsforløb og identitet inden for den politiske journalistik. De forsider, der her vil blive diskuteret, skal således forstås som en synkron skive, der er skåret ud af den proces, hvor igennem Khaders politiske identiteter løbende konstrueres som nyheder i den trykte presse, en proces, der i stor udstrækning sker i relation til det, der er gået forud (som jeg var inde på ovenfor).

En foreløbig ramme for en sådan analyse kan findes i den antologi, der var resultatet af forskningsprojektet „Politisk Journalistik - historie og udvikling“, der løb fra 1997-2000. I en af artiklerne i denne antologi skriver Ove K. Pedersen og Maja Horst med hensyn til udviklingen af den politiske journalistik i Danmark siden anden verdenskrig, at:

„Det reservoir af menneskelige handlinger som journalisten (og politikeren) kan gøre til en politisk nyhed, er blevet større - betydeligt bredere; ligeledes er antallet af ny- 
hedskriterier, som redaktionen kan lægge til grund for valg af politisk nyhed, blevet forøget - mere mangesidet. Samtidig er grænserne mellem den politiske journalistik og andre journalistiske genrer blevet porøse.“

(Pedersen og Horst, 2000: 170-71).

I diskussionen af denne udvikling argumenterer Pedersen og Horst for et overordnet skift fra et fokus på politiske hændelser, konkrete episoder, fx politiske debatter i Folketinget til begivenheder, der skabes igennem en faktisk eller iscenesat interaktion imellem politikere og/eller imellem disse og journalister. Begivenheden er således ikke nødvendigvis kædet til en faktisk hændelse. En typisk politisk (nyhed/)begivenhed er et „problem“, der "afsløres“ af enten politikere eller journalister (i samarbejde med politikere). Det overordnede argument er, at den politiske hændelse stort set er forsvundet som basis for den politiske journalistik hen imod slutningen af det 20. århunderede. En anden måde at sige dette på er, at de fleste hændelser omformes til begivenheder ved at blive indsat i en større fortællemæssig ramme - som det vil fremgå af dækningen af etableringen af Ny Alliance. Pedersen og Horst kalder den journalistik, der var knyttet til hændelsen for „referentiel“, mens den journalistik, der knyttes til begivenheden kaldes „dialogisk“, idet denne er et resultat af en iscenesættelse af en dialog imellem politikere, citater og journalister, der tidsmæssigt kan strække sig over lange perioder. I relation til disse typer af politisk journalistik argumenterer de for fire fremtrædende fortællemåder: 1) referentiel, 2) videnskabelig, 3) dramatisk og 4) episk. Jeg vender tilbage til nogle af disse i analysen nedenfor (Pedersen og Horst, 2000: 172-3).

Hvis man ser på etableringen af Ny Alliance i forhold til en sådan overordnet ramme, synes dette umiddelbart som en politisk hændelse, der ligger tæt på kernen af stofområdet for den klassiske politiske journalistik i den forstand, at denne primært fokuserede på:

„... en hændelse der kan stedfæstes og tidsfæstes, hvor tid og sted er objektive størrelser, og hvor genstanden er politisk, fordi hændelsen foregik i institutioner, der konstitu- 
tionelt (ved Grundloven) er udpeget til at være politiske (Folketinget f.eks.) og mellem personer, der efter loven (Valgloven) er defineret som politikere (medlemmer af Folketinget f. eks.).“ (Pedersen og Horst, 2000: 172).

Hvis vi følger denne karakteristik og det dertil hørende argument om udviklingen af den politiske journalistik, er etableringen af Ny Alliance således ikke en god case for en nærmere undersøgelse af den nutidige praksis omkring politiske nyheder. Etableringen af Ny Alliance synes som prototypen på en politisk hændelse, idet den er tæt forbundet med de parlamentariske processer og ydermere kan kædes til konkret tid og sted, nemlig den pressekonference, hvor det blev offentliggjort. Man kan imidlertid ikke sige, at en sådan hændelse hører til de politiske processers normale rytme. Og man kan også sige, at selvom selve hændelsen er interessant fra et journalistisk perspektiv, så er de sager, personlige relationer og ambitioner, der førte til hændelsen, og de konsekvenser denne kan have, i lige så høj grad interessante, og det er igennem sådanne foci, at hændelsen transformeres til en række begivenheder. De begreber, som Pedersen og Horst bringer i spil, er netop relevante, idet de kan hjælpe os til at se nærmere på, hvorledes en specifik hændelse omformes til en politisk begivenhed igennem forskellige måder at fortælle på. Dette fremgår klart, hvis vi ser nærmere på de 11 forsider fra d. 8 . maj.

B.T. (T):

Ekstra Bladet (T):

metroXpress (F):

Nyhedsavisen (F):
„KONG KHADER“; Underoverskrif(er): „Ring til Khader \& Co. på B.T. i dag * Konen: Jeg gav ham lov * Jelved slået groggy“ (Foto: en tilfreds Khader (lille)).

„Den smilende RAMBO“; Underoverskrift: „Jelved skamskudt efter Khaders raid“ (Foto: en grinende Khader (stort)). „Khader stækker Pia K“ (Foto: Khader på vej ned ad trappen fra Christiansborg sammen med Seeberg og Samuelsen alle med et (selv-)tilfreds smil på læben). 
24timer (F):

BerlingskeTidende (S): „Khader bag politisk jordskred“; Underoverskrift: „Naser Khaders stiftelse af partiet Ny Alliance tegner et helt ny politisk danmarkskort. Flere radikale topfolk går med tanker om at følge Khader, Gitte Seeberg og Anders Samuelsen, ligesom erhvervslivet støtter det nye parti. Samtidig viser en ny Gallup-måling, at $26 \%$ af danskerne overvejer at stemme på Khaders parti ved et kommende valg. (Foto: Khader på vej ned ad trappen fra Christiansborg sammen med Seeberg og Samuelsen - alle med et (selv-)tilfreds smil på læben).

Politiken (S): $\quad$ „Da Naser Khader gjorde en stille mandag til Danmarkshistorie“; Underoverskrift: „Naser Khader skrev politisk historie, da han forlod Det Radikale Venstre for at etablere sit eget parti - Ny Alliance. Dermed kan Khader ende med at få indflydelse på hvem der skal sidde i Statsmi- 
Urban (F):

Jyllands-Posten (S):

Information (S):

Børsen (S): nisteriet efter næste valg“. (Foto: Seeberg, Khader og Samuelsen, der kigger i retning af kameraet. Khader taler tilsyneladende, mens de andre lytter).

„Nye stemmeslugere“; Underoverskrift: „11 procent af danskerne vil med sikkerhed eller sandsynligvis stemme på det nye parti - Ny Alliance - med Naser Khader i spidsen, viser meningsmåling.“ (Foto: Khader, Seeberg og Samuelsen, alle smilende, ved pressekonferencen).

„OPRØR FRA MIDTEN“; Underoverskrift: „Khaders nye parti vil udmanøvrere Dansk Folkeparti“. (Foto: en koncentreret og sober Khader med en kop kaffe på hovedbanegården (mellem-størrelse)).

„Et socialliberalt, borgerligt, socialkonservativt, globaliseringsvenligt, antiDansk Folkeparti, humanistisk velfærds- og midterparti.dk?“; Underoverskrift: „Gitte Seeberg, Naser Khader og Anders Samuelsen dannede i går et ny parti, Ny Alliance. Men er det nok at have ikonet Khader som politisk frontfigur, en ide om en ny alliance og et ønske om at holde Dansk Folkeparti fra magten? Ny Alliance balancerer på en knivsæg mellem at blive en meget lille parentes og et historisk nybrud i dansk politik“. (Foto: Khader, Seeberg og Samuelsen ved pressemødet. Khader taler, mens de to andre lytter koncentreret (mellem-størrelse)).

„Ny Alliance ønsker stor skattereform“ (Foto: En alvorlig Khader på vej hen ad gangen på Christiansborg med Samuelsen og Seeberg efter sig (mellem-størrelse)). 
De 11 overskrifter er angivet i rækkefølge med hensyn til den vægt, der lægges på henholdsvis Khader som person, Ny Alliance som parti (og dets potentielle mulighed for at flytte stemmer) og endelig de mulige lovgivningsmæssige konsekvenser. Det kommer ikke som nogen overraskelse, at rækkefølgen er korreleret med en overordnet inddeling i (T)abloidaviser, de to første, (S)eriøse (hvoraf de fleste kommer sidst i rækkefølgen) og så de fire (G)ratisaviser, der befinder sig i midtergruppen. Denne rækkefølge baseret på en inddeling af overskrifterne passer ydermere udmærket med de tilhørende billeder. Der er fire aviser, der har et billede, der udelukkende viser Khader (B.T., Ekstra Bladet, 24timer \& Jyllands-Posten). De resterende har billeder af de tre personer, der etablerede partiet sammen (Khader, Seeberg og Samuelsen). At Khader på alle disse billeder er i midten, synes mere et bevidst valg fra gruppen end en foto-journalistisk iscenesættelse. Nyhedsavisen er den eneste avis, der udskiller sig her, idet den har et billede af Khader og Samuelsen, hvor sidstnævnte optræder forholdsvis ufokuseret i baggrunden.

Hvis vi sætter overskrifterne i relation til de fire fortællemåder i den politiske journalistisk, så falder de to første - „Kong Khader“ og „Den smilende Rambo“ (B.T. og Ekstra Bladet) - klart inden for den episke form. Pedersen og Horst skriver med hensyn til denne, at:

genstanden ... er en politisk begivenhed ... hvori der inddrages personer som er legitime politiske deltagere eller berørte parter, og hvor journalisten lader dem indgå i konflikter som er personificerede frem for ideologiske eller politiske, og hvor det er journalisten selv der tilkender deltagerne episke dimensioner - at være helt eller skurk, offer eller synder, dum eller klog.“ (Pedersen og Horst, 2000: 173)

Selvom „Kong[e]“ og „RAMBO“ peger på to meget forskellige kontekster, og derfor giver en række uensartede associationer, så peger de begge på en forbindelse imellem magt og vold og/eller undertrykkelse. Og dette er i begge aviser understreget og udvidet igennem underoverskriftens referencer til den sårede part, nemlig Marianne Jelved. Khader karakteriseres dermed som en 
noget hensynsløs politiker, der ikke vil dele magten og/eller opmærksomheden med andre. Politik bliver igennem denne vinkling konstrueret som et voldsomt og strategisk spil, der begunstiger bestemte typer af mennesker og sårer andre. Dette kommer også tydeligt frem i overskriften i metroXpress, hvor „Khader stækker vingerne på Pia K“. Men på trods af, at de domæner, der refereres til i disse tre overskrifter (det royale, Hollywood filmstjerner og husdyr) ved første øjekast ser ud til at positionere det politiske langt fra det liv, der kendetegner de fleste læseres/vælgeres liv, så er der elementer, der trækker i en anden retning.

Det foto, der ledsager overskriften „Khader stækker vinger på Pia K“, viser Khader, Seeberg og Samuelsen, der kommer læserne/forografen i møde på vej ned ad trapperne fra Christiansborg. Det er, som om billedet signalerer en gruppe på vej ud fra borgen efter et veludført arbejde, og bevægelsen i billedet antyder samtidig, at der her bygges bro imellem livet i Folketinget og så livet udenfor. En sådan betydning kan også læses ud af B.T.s forside, hvor der umiddelbart under overskriften „Kong Khader“ og billedet opfordres til, at læserne ringer til Khader på avisen. Kongen taler tilsyneladende med almindelige mennesker! Med hensyn til Ekstra Bladets reference til RAMBO kan man sige, at læsernes opfattelse af Khader og politik her filtreres igennem et oplevelsesområde, hvor vi som kulturforbrugere er vant til identificere med (hoved)personer i relation til en given fortælling. Snarere end at skubbe det politiske domæne væk, så gør en sådan tilgang det snarere genkendeligt og forståeligt. Det skal samtidig understreges, at RAMBO trods alt er en forholdsvis klassisk individualistisk helt, der arbejder imod det onde, og at det danske kongehus bærer associationer om kompetence og forståelse. Igennem disse referencer bliver karakteristika forbundet med magt og styre gjort både mere specifikke og mere generelle i den forstand, at der igennem denne persontegning fremsættes en parallel imellem politikkens sociale processer og så sociale processer i mere almindelighed. Det er samtidig værd at bemærke, at både kongehuset og Hollywood er områder, der i udpræget grad er karakteriseret ved deres mediemæssige fremstilling, fremstillinger, der åbenlyst er konstrueret men ikke desto mindre - eller netop derfor - anses som væsentlige. 
Hvis vi ser på de andre dagblade, så er der også her en lignende tendens til at personliggøre det politiske område. I mange overskrifter er det Khader, der har „rystet dansk politik“, stået bag et „politisk jordskred“ eller „forvandlet et stille mandag til dansk historie“. Og i de fleste overskrifter er det simpelthen „Khaders“ parti (kongen?). De eneste aviser, der ikke anfører Khader som hovedperson, er Børsen og Information. Førstnævnte er i øvrigt den eneste avis ud af de 11, der på overskriftsniveau anfører de mulige lovgivningsmæssige konsekvenser af det nye politiske landskab. De resterende aviser er i større eller mindre grad optaget af politik som en strategisk konkurrence eller proces. Dette er i sig selv ikke noget nyt. Joan Didion skrev for nogle år siden i Political Fictions om sine oplevelser som en del af pressekorpset i forbindelse med det amerikanske præsidentvalg, at mange (de fleste?) mediefolk taler om „processen som et mål i sig selv, der kun ved navn, og yderst perifert, er forbundet til det der interesserer vælgerne“ (Didion, 2000: 21). Som jeg har peget på, er processen igennem sin persontegning dog ikke uden betydning for vælgerne. Dette kommer også frem, omend i en anden form end i tabloidaviserne, i underoverskriften på Information, hvor Khader karakteriseres som et „ikon“ i front for et parti, hvis politik er relativt uspecificeret - hvilket vises igennem den lange liste i overskriften med et spørgsmålstegn efter. Det er ydermere værd at lægge mærke til tilføjelsen af domænenavnet „.dk“, der synes at stille spørgsmålet, om vi her står over for en ny type partipolitik, hvor partier er mere løst definerede og fleksible netværk, der løbende og på pragmatisk vis genereres igennem sociale netværksdannelser på internettet. Den offentlige person, der står i spidsen for et parti, har længe været vigtig som repræsentation både i en systemisk forstand og som værdimæssigt knudepunkt. Når politikken skal konstrueres ud fra personen snarere end omvendt bliver denne funktion ikke alene endnu vigtigere; den stiller også andre krav til knudepunktet, igennem hvilket forskellige sager skal koordineres og gives udtryk.

At opbygge sådan en partipolitisk offentlighed tager tid, og både Khader og aviserne må derfor trække på en bred vifte af de konstruktioner af Khader som offentlig person, der er opbygget igennem de mange mediemæssige sammenhænge, han har op- 
trådt i de sidste mange år. En mere tilbundsgående analyse må derfor tage de forskelligt konstruerede livsforløb med i betragtning. I den forbindelse er det nødvendigt at fokusere på, hvad det er ved politiske liv, der gør dem til udvidet genstand for journalistisk interesse - ud over det, at de ligger „bag“ en offentlig stilling eller funktion. Et foreløbigt svar er, at det journalistiske instinkt går efter konflikter og/eller det modsætningsfyldte i politiske livsforløb. Kan Hillary virkelig være så rationel og strategisk? Er der ikke en „ægte“ kerne af kvindelighed gemt et eller andet sted? Med hensyn til Khader giver hans lidt utraditionelle baggrund, der blev præsenteret ovenfor, også anledning til spørgsmål, fx hvordan kan han forene sin muslimske baggrund med de krav, der stilles i et sekulært demokrati? Nogle politikere legemliggør således en række prægnante spørgsmål - og det er derfor, at jeg ovenfor refererede til Khader som et knudepunkt, en ide, der bygger videre på John Corners beskrivelse af politiske frontfigurer, som noget der „kondenserer 'det politiske'“, og som ydermere bliver „fokus for politiske værdier og ideer på en måde, der rækker ud over deres konkrete politiske virke“. Der er, med andre ord, siger Corner, „en symbolsk merværdi i den politiske figur, ... der overskrider en rationel tilknytning til konkrete politikker" (Corner, 2003: 80). Den „symbolske merværdi“, som Khaders offentlige person besidder er dog, som hos Hillary, udvidet i den forstand, at hans politiske liv tiltrækker sig ekstra offentlig og/eller journalistisk interesse, fordi vigtige politiske og kulturelle skillelinjer eller fronter støder sammen i livsforløbet.

Mens Khader for nogle er et fornemt eksempel på integration og pragmatisk politik, er han for andre, specielt fra indvandrermiljøet, en, der har solgt ud af sin religiøse og kulturelle baggrund og opvækst for at få adgang til det danske samfund (en højt profileret husslave, der nyder opmærksomheden og privilegierne på bekostning af dem, der må forblive i marken, for at bruge et billede fra de amerikanske sydstater). Den overordnede pointe er her, at ved at forholde sig til Khader som person forholder man sig derfor til vigtige politiske spørgsmål. Det at konstruere og percipere et livsforløb og en offentlig person kan ikke adskilles fra det at konstruere politik, og det vil, vil jeg påstå, være fejlagtigt at stille sig på Habermas' side, når han i en forholdsvis ny artikel 
skriver at „ud over personliggørelse, så promoverer dramatiseringen af begivenheder, simplifikationen af komplekse forhold, og den udprægede polarisering af konflikter, en civil privatisme og modvilje imod politik“ (Habermas, 2006: 422).

Man bør være mere forsigtig med godtage og videreføre den dikotomi, der ofte opstilles imellem rationel deliberation og emotionel identifikation, og deraf følgende modstilling imellem politisk substans og image. Michael Tomasky skriver i en anmeldelse af en netop udgivet og i denne sammenhæng interessant bog af Drew Westen med titlen The Political Brain: The Role of Emotion in Deciding the Fate of the Nation, at:

det sprog der anvendes af politikere [og journalister] igangsætter et netværk af associationer i hovedet på vælgerne. Disse associationer, selv for dem som følger aktuelle begivenheder tæt, er mere tilbøjelige til at være emotionelle end rationelle, og vælgerne 'argumenterer' sig frem til følelsesmæssigt baserede konklusioner ...

Westens hovedpointe er både klar og simpel: Demokraterne, skriver han, har overordnet set taget det for givet at vælgerne beslutter sig på baggrund af fornuft og dette har slået fejl fordi den 'politiske hjerne er en følelsesmæssig hjerne.'“ (Tomasky, 2007: 37).

Dette argument er i høj grad værd at forfølge nærmere i relation til konstruktionen af politiske liv. Som jeg har antydet ovenfor, så kan den journalistiske konstruktion af politiske liv ikke ses som isoleret fra de processer, hvor igennem læserne tilskriver betydning. Og hvis vi følger Anthony Giddens, så er det at forholde sig til sådanne livsforløb en vigtig brik i konstruktionen af identitet og selvforståelse. Giddens skriver, at en person med „en forholdsvis stabil opfattelse af sin selvidentitet samtidig har en følelse af biografisk kontinuitet“ og at ,identitet ikke findes i opførsel eller $i$ andres reaktioner - selvom disse er vigtige - men snarere i evnen til at bibeholde en bestemt fortælling“ (Giddens, 1991: 54). Set fra et sådant perspektiv er de i stigende grad uklare skillelinjer, der er imellem den politiske journalistik og andre genrer, måske ikke noget der skal beklages, idet forskellige journalistiske fremstil- 
linger af sammenhænge og modsætninger i politiske livsforløb er et vigtigt råmateriale for at forstå både sig selv og det politiske i en bredere forstand. Og hvad Hillary Clinton virkelig føler, er i den sammenhæng kun af retorisk betydning.

\section{N OTER}

1. Citater fra engelsksprogede kilder er oversat af Henrik Bødker.

\section{REFEREN CER}

Conboy, Martin (2006[2004]). Journalism - A Critical History, London: SAGE.

Corner, John (2006 [2003]). "Mediated Persona and Political Culture", pp. 86-84 I: John Corner \& Dick Pels (red.), Media and the Restyling of Politics. London: SAGE.

Giddens, Anthony (1991). Modernity and Self-Identity: Self and Society in the Late Modern Age. Stanford: Stanford University Press.

Haberrmas, Jürgen (2006). "Political Communication in Media Society: Does Democracy Still Enjoy an Epistemic Dimension? The Impact of Normative Theory on Empirical Research", Communication Theory, no. 16 , pp. 411-426.

Kolbert, Elizabeth (2007). "The Lady Vanishes: Two biographies search for the real Hillary Clinton”, The New Yorker, d. 11. \& 18. juni, 2007.

Pedersen, Ove K. \& Horst, Maja (2000). „Dialogjournalistikken - Nutidens politiske dagsorden“, i Pedersen, Ove. K. et.al. (red.), Politisk journalistik. Aarhus: Ajour.

Tomasky, Michael (2007). "How Democrats Should Talk", The New York Review of Books, 31. maj. 